\title{
Risk perception at a persistently active volcano: warnings and trust at Popocatépetl volcano in Mexico, 2012-2014
}

\author{
Amy Donovan ${ }^{1}$ (D) Irasema Alcántara Ayala ${ }^{2}$ - J. R. Eiser ${ }^{3}$ - R. S. J. Sparks ${ }^{4}$
}

Received: 25 September 2017 / Accepted: 20 March 2018 / Published online: 13 April 2018

(C) The Author(s) 2018

\begin{abstract}
This paper presents data from an online survey carried out in Mexico from 2012 to 2014. The survey focussed on the risk to Mexico City from Popocatépetl, an active volcano $60 \mathrm{~km}$ from the city. During the time period, volcanic activity was variable, and the alert level changed accordingly. The survey showed that people surveyed at the higher alert level were generally more concerned about the volcano. Since these people were measured separately from those who responded at the lower alert level and yet self-reported on the same scale as more concerned, this provides a useful indicator that the raised alert level may be associated with higher risk perception, and that alert level systems act as boundary objects in the translation of scientific information. In general, trust in various groups was most strongly explained by the perceived knowledge of the groups, followed by their perceived motivation (whether or not they are viewed as working in society's interest), with accuracy a tertiary concern. Some respondents were anxious about false alarms - these people also tended to be concerned about scientific accuracy while those who favoured precaution tended to be more trusting. The perceived effectiveness of warning and evacuation plans was also a significant predictor for trust in official groups. In general, the results suggest that there are important links between trust, warning plans and the perceived motivation of particular groups as well as between trust and perceived knowledge.
\end{abstract}

Keywords Volcanic risk $\cdot$ Risk perception $\cdot$ Early warning $\cdot$ Science and policy $\cdot$ Decision-making

Editorial responsibility: C. Bonadonna

Electronic supplementary material The online version of this article (https://doi.org/10.1007/s00445-018-1218-0) contains supplementary material, which is available to authorized users.

Amy Donovan

amy.donovan@kcl.ac.uk

Irasema Alcántara Ayala

irasema@igg.unam.mx

J. R. Eiser

j.r.eiser@shef.ac.uk

R. S. J. Sparks

steve.sparks@bristol.ac.uk

1 Department of Geography, King's College London, The Strand, London WC2R 2LS, UK

2 Instituto de Geografía, Universidad Nacional Autonoma de Mexico, Cd. Universitaria, DF CP 04510 Deleg. Coyoacán, Mexico

3 Department of Psychology, Western Bank, University of Sheffield, S10 2TP, Sheffield, UK

4 School of Earth Sciences, University of Bristol, Queen's Road, Bristol BS8 1RJ, UK

\section{Introduction}

Previous studies have found differences in risk perception according to gender, religious belief, experience of previous hazards and distance from the volcano (Chester et al. 2008; De la Cruz-Reyna and Tilling 2008; Haynes et al. 2008; LópezVázquez 2009; Newhall and Punongbayan 1996). Perceived risk affects the impact of risk communication, and a key challenge for scientists and decision-makers during volcanic events has been to communicate effective warnings that change behaviour (Perry and Lindell 2008). A range of approaches to this have been proposed, including warning systems (De la Cruz-Reyna and Tilling 2008; Fearnley and Beaven 2018) and the engagement of trusted groups or individuals in the process (Haynes et al. 2008). Understanding how people decide to place trust in particular groups or individuals during volcanic crises is important in ensuring effective communication strategies. It also enables the formation of holistic plans to engage with the community in advance of an emergency, to empower communities to act and to identify their vulnerabilities (Alcántara-Ayala 2004).

It has long been recognised that public trust in risk communicators, and in the management and regulation of hazards, 
has important implications for people's perceptions of risk and their readiness to take precautionary action (see Eiser et al. 2012 for a review within the context of environmental risks; see also Cvetkovich and Lofstedt 1999; Eiser et al. 2002; Renn and Levine 1991; Siegrist and Cvetkovich 2000; Slovic 1993; Van der Pligt 1992). The present research and selection of dependent measures is based on a theoretical framework termed the intuitive detection theorist model by White and Johnson (2010) (see also Eiser 1990; White and Eiser 2007), which comprises the following features.

Firstly, a key element of risk perception is a judgement under uncertainty of how safe or dangerous a particular hazard may be; in other words, a discrimination between potential danger and safety. Applying a distinction derived from signal detection theory (Swets 1973), the quality of any such judgement can be characterised in terms of two parameters: (a) sensitivity or discrimination ability (i.e. overall accuracy) and (b) bias, or the use of a decision criterion resulting in either riskier or more cautious decisions, as revealed by the relative proportions of false negative and false positive errors. Crucially, there is no absolute answer to the question of what constitute a 'good' decision criterion: it depends primarily on the benefits and costs, actual and/or perceived, of different outcomes. For example, if a 'false alarm' is seen as less costly than failure to warn the public before an actual eruption, this is likely to motivate decision-makers to adopt a more precautionary criterion (Woo 2008). Recent research has linked such biases towards risk or caution to principles of experiential learning and approach-avoidance behaviour (Eiser and Fazio 2008; Fazio et al. 2004) as well as to more general individual differences in personality and motivation (Fazio et al. 2015). Secondly, we very frequently need to rely on other people's judgement of risk in order to make appropriate choices under uncertainty. This raises the question of how much these other people (e.g. risk communicators or managers) and their judgments are to be trusted (Sjoberg 2008; White and Johnson 2010). Trust is conceptualised as a social judgement involving implicit assessment of (a) how accurately such risk communicators can discriminate danger from safety (discrimination ability), (b) their tendency to interpret risks as more or less dangerous (response bias) and (c) their propensity to be open and honest with the public about events (communication bias) (Eiser et al. 2012). Just as response bias may reflect benefits and costs of potential outcomes, perceived communication bias may be influenced by suspected vested or commercial interests on the one hand or by social affinity between communicators and the public on the other (Eiser et al. 2012; White and Eiser 2006). This framework has been shown to predict both levels of trust in particular communicators, and relative preferences between different information sources or agencies, in relation to a variety of environmental, industrial and medical risks (Eiser et al. 2015; Eiser et al. 2007; Eiser et al. 2009; White et al. 2011).
Several studies have addressed the issue of early warning in risk reduction (Garcia and Fearnley 2012; Leonard et al. 2008; Mileti and Sorensen 1990; Sorensen 2000), particularly with reference to the challenges of avoiding so-called 'false alarms' (Dillon and Tinsley 2008; Tinsley et al. 2012). This concern among volcanologists emerged into prominence following the phreatic eruption of $\mathrm{La}$ Soufrière de Guadeloupe in 1976, when an evacuation took place at great economic cost but no magmatic eruption occurred (Tazieff 1977). Hincks et al. (2014) provided an analysis based on a Bayesian belief network that indicated that, given the state of knowledge at the time, the evacuation in the 1976 crisis was justified. While subjective probabilistic methods such as this are important in aiding scientific risk assessment, there are also implications for risk communication and risk perception-particularly as the communication of probabilistic values is challenging (Donovan et al. 2015; Doyle et al. 2014; Gigerenzer et al. 2005). It is useful, therefore, to understand public attitudes towards uncertain information, particularly in terms of potential outcomes. Such information is likely to be context-sensitive and not universal (Garcia and Fearnley 2012).

Volcanic alert levels, like that in Fig. 2 for Popocatépetl, provide important communication tools for volcanologists and are widely used (Fearnley and Beaven 2018). As in other hazard domains, alert level systems are boundary objects: they allow communication across the 'boundary' between science and society (Star and Griesemer 1989) and may serve different functions on each side. They may also be used to order that boundary by reconciling the uncertainty of science with its authority and providing some linearity to the boundary (Donovan and Oppenheimer 2014; Donovan et al. 2012; Donovan and Oppenheimer 2015; Gieryn 1983; Shackley and Wynne 1996). In volcanic contexts, they are used in a variety of ways but typically have a major role in communication (Fearnley et al. 2012). Understanding how individual systems function as communicators in particular contexts is thus significant.

In 2012-2014, we conducted a risk perception survey concerning Popocatépetl. Data collection was carried out using Internet advertisements on the University of Mexico (UNAM) and Centro Nacional de Prevencion de Desastres (CENAPRED) websites. The survey was designed to analyse local people's perceptions of the risk, their views about the reliability of sources of information and the reasons behind those views. They were also asked about the effectiveness of warning plans, likely consequences of eruptive activity, and their views about precaution and false alarms. The aim was to investigate the roles of trust and precaution in perception of risk and to identify links between trust and perceived bias, accuracy and motivation. 


\section{Background}

Popocatépetl is a stratovolcano approximately $60 \mathrm{~km}$ from Mexico City (Fig. 1). It has been persistently active since 1994, with intermittent explosive activity. In December 2000, 41,000 people were evacuated for several days due to heightened activity (De la Cruz-Reyna and Tilling 2008). The volcano is monitored by the UNAM in collaboration with the disaster prevention agency of Mexico (CENAPRED). A three-tier alert level system is in place, with several stages in each tier-shown in Fig. 2 (De la Cruz-Reyna and Tilling 2008). The alert level system is managed by the CENAPRED in collaboration with the civil protection, scientific advisory committee and government offices. During 2012-2014, the alert level changed between yellow phase 2 and yellow phase 3 . A timeline of the eruptive history during the period covered by this paper is given in Table 2 . Popocatépetl has a long history of eruptions throughout the time of human habitation in the region (Plunket and Uruñuela 2006; Siebe and Macías 2006), ranging from mild to moderate VEI 1-4 eruptions in recent years to VEI 5-6 eruptions over much longer timescales (Boudal and Robin 1989; De la CruzReyna and Tilling 2008; Plunket and Urunuela 2006). The history and understanding of the volcano have evolved significantly in recent decades, while the population has increased to over 20 million (De la Cruz-Reyna and Tilling 2008).

Several recent studies have examined aspects of risk perception and management at Popocatépetl during the ongoing eruptions (De la Cruz-Reyna and Tilling 2008; LópezVázquez 2009; López-Vázquez and Marván 2012; LópezVázquez et al. 2008; Tobin et al. 2007; Tobin et al. 2011). Long-lasting volcanic eruptions are a particular challenge for scientists, civil protection and populations. Such eruptions can involve rapid changes in volcanic activity that place considerable pressure on decision-makers (De la Cruz-Reyna and Tilling 2008). In areas of high population density, this

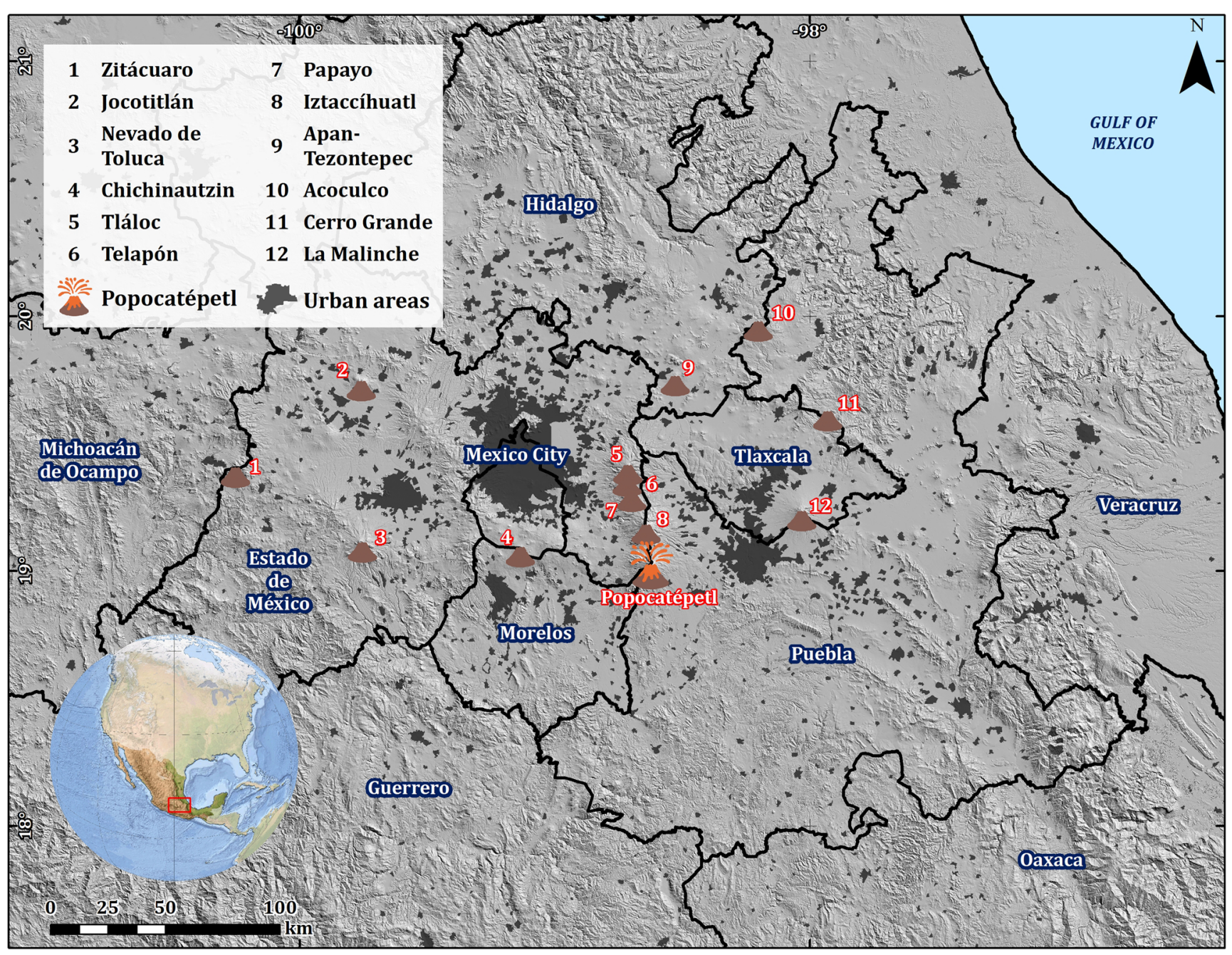

Fig. 1 Map of eastern Mexico, showing the volcanoes around Mexico City (Distrito Federal—residential areas in grey). Popocatépetl is the larger red triangle. Volcano data from the Large Magnitude Eruption Database (LaMEVE; Crosweller et al. 2012) 


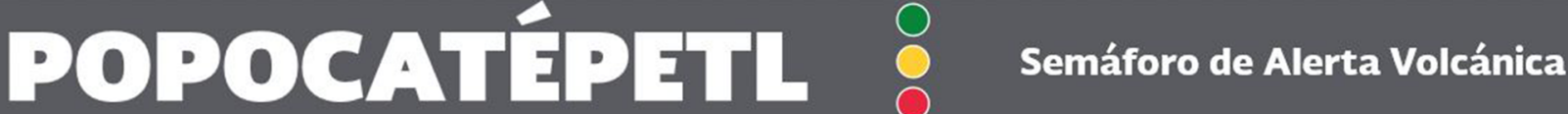

NORMALIDAD Infórmate. Conoce las rutas de evacuación, sitios de reunión y refugios temporales.
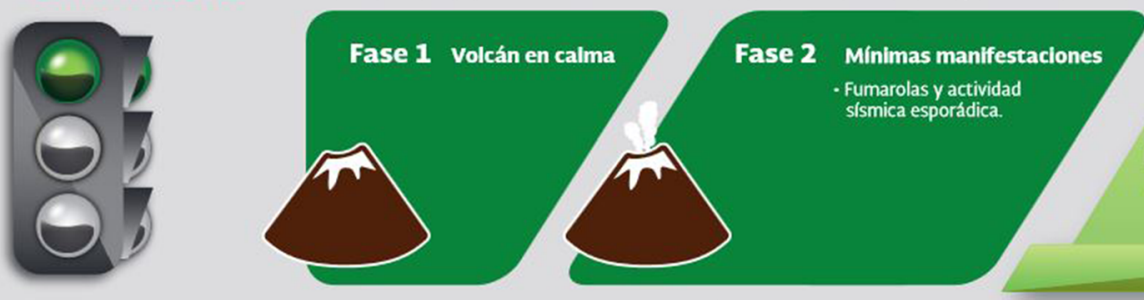
y monitoreados a nivel mundial.

En un radio de menos de $100 \mathrm{~km}$ del cráter, habitan 25 millones de personas.

AIERTA

Permanece atento y prepárate para una posible evacuación.
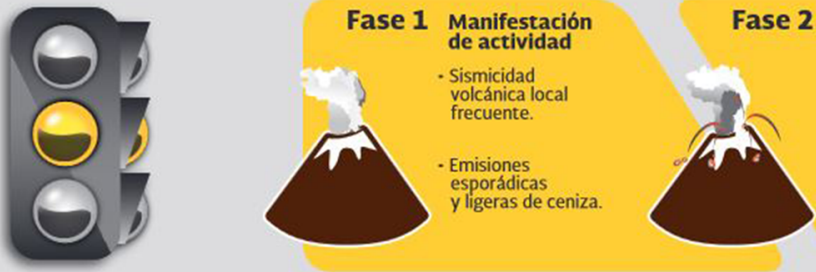
Incremento de actividad Pluma de vapor de agua y gas. Ligera calda de ceniza en areas cercanas. incandescentes. Posibilidad de flujos piroclásticos por explosiones. Flujos de lodo o escombros de corto alcance.

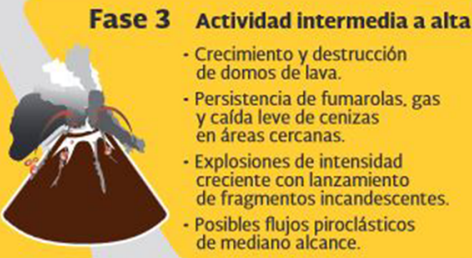

ALARMA

Hay peligro. Tú y tu familia deben estar listos para la evacuación.

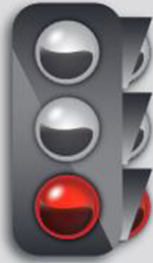

Fig. 2 The volcanic alert level system at Popocatépetl (source: CENAPRED). In English, the main text reads as follows: normal (green), stay informed, know evacuation routes, meeting points and

challenge is particularly acute as the level of risk fluctuates, population response can struggle to keep up and people can become either paralysed by fear or complacent as they become used to the risk. Tobin et al. (2011) found differences in risk perception between sites with chronic hazard from Popocatépetl and those with acute (i.e. short-term) hazard from landslides (unrelated to volcanic activity but also in Puebla state), noting that perceptions of risk from the volcano were generally lower. Attitudes to the volcano are not necessarily negative; many respondents viewed the volcano as having positive impacts on their lives (Tobin et al. 2007).

\section{Methods}

\section{Survey design}

The survey was designed to investigate the perceived hazards and risks from Popocatépetl and the trust of the respondents in different groups. Initially, demographic data were requested. The information included age, gender, level of education, job and the distance that the respondent lived from the volcano. They were also asked how long they had lived close to the volcano. They were then asked questions about volcanic hazards (asking separately how likely the hazards were to occur and how far they might travel), forecasting and risk management and their beliefs about eight specific groups (see Table 1 for groups). These questions are summarised in Table 1. The survey was targeted at adults of all ages.

The survey was derived from previous work (Donovan et al. 2014; Donovan et al. 2015; Eiser et al. 2015) and had been pretested as part of that work. Ethical approval was obtained prior to commencing the research. The survey was administered in Spanish. Its primary purpose was to understand relationships between risk perception, trust, perceived motivation and decision-making. As such, we focussed on the distance from the volcano (for statistical power) rather than mapping the locations of respondents. Future work will examine spatial variations in risk perception around the volcano at closer proximity to the crater. 
Table 1 Summary of survey questions

\begin{tabular}{|c|c|c|}
\hline Variable group & Question & Response type \\
\hline Concern & How concerned are you about the volcanic activity at Popocatépetl? & $\begin{array}{l}\text { 7-point scale; } 1 \text { = not at all concerned; } \\
7=\text { extremely concerned }\end{array}$ \\
\hline $\begin{array}{l}\text { Hazard likelihood } \\
\quad \text { (in general) }\end{array}$ & $\begin{array}{l}\text { How likely is Popocatépetl to produce the following hazards? } \\
\text { (lava flow, ashfall, pyroclastic flow, explosive eruption, } \\
\text { debris avalanche, mud flow, gas emission) }\end{array}$ & $\begin{array}{l}\text { 7-point scale; } 1 \text { = very likely; } \\
7 \text { = very unlikely }\end{array}$ \\
\hline Hazard magnitude & $\begin{array}{l}\text { How far do you think a [lava flow, pyroclastic flow, ash cloud] } \\
\text { could travel from Popocatépetl? }\end{array}$ & Open textbox \\
\hline Frequency & $\begin{array}{l}\text { How frequent are eruptions at Popocatépetl? } \\
\text { (e.g. every day, every month) }\end{array}$ & Open textbox \\
\hline Forecast & $\begin{array}{l}\text { How easy or difficult do you think it is for scientists to forecast } \\
\text { activity from Popocatépetl from [week to week, year to year]? }\end{array}$ & $\begin{array}{l}\text { 7-point scale; } 1 \text { = extremely easy; } \\
\quad 7=\text { extremely difficult }\end{array}$ \\
\hline Knowledge & $\begin{array}{l}\text { How much knowledge about volcanic activity at Popocatépetl } \\
\text { do you think each of the following groups has? (scientists, } \\
\text { Mexican government, local government, friends and family, } \\
\text { religious leaders, social networks, news media) }\end{array}$ & $\begin{array}{l}\text { 7-point scale; } 1=\text { very little knowledge; } \\
7=\text { a great deal of knowledge }\end{array}$ \\
\hline Over/underestimate & $\begin{array}{l}\text { How likely are each of the following groups to over or under } \\
\text { estimate the risk associated with the activity of Popocatépetl? } \\
\text { (groups as previous) }\end{array}$ & $\begin{array}{l}\text { 7-point scale; } 1=\text { not at all likely; } \\
\quad 7=\text { extremely likely }\end{array}$ \\
\hline Societal interest & $\begin{array}{l}\text { How much importance would each of the following groups attach } \\
\text { to serving society's interests in relation to the activity } \\
\text { of Popocatépetl? (groups as previous) }\end{array}$ & $\begin{array}{l}\text { 7-point scale; } 1=\text { no importance; } \\
7=\text { a great deal of importance }\end{array}$ \\
\hline Trust & $\begin{array}{l}\text { How much do you trust information from the following groups } \\
\text { about the activity of Popocatépetl? (groups as previous) }\end{array}$ & $\begin{array}{l}\text { 7-point scale; } 1=\text { do not trust at all; } \\
7=\text { trust completely }\end{array}$ \\
\hline $\begin{array}{l}\text { Statements on trust } \\
\text { and precaution }\end{array}$ & $\begin{array}{l}\text { To what extent do you agree with the following statements? } \\
\text { (If too many warnings are given, people stop taking them } \\
\text { seriously; It's always better to be safe than sorry; If one thinks } \\
\text { there's any risk at all, the public must be warned; Warnings } \\
\text { that turn out to be unnecessary do more harm than good) }\end{array}$ & $\begin{array}{l}\text { 7-point scale; } 1 \text { = strongly disagree; } \\
7=\text { strongly agree }\end{array}$ \\
\hline Evacuation & $\begin{array}{l}\text { In the case of a major eruption of Popocatépetl, how necessary } \\
\text { do you think it would be to evacuate people in the area } \\
\text { [temporarily/permanently]? }\end{array}$ & $\begin{array}{l}\text { 7-point scale; } 1=\text { not at all necessary; } \\
7=\text { very necessary }\end{array}$ \\
\hline Impact & $\begin{array}{l}\text { If a major eruption occurs at Popocatépetl, how serious would } \\
\text { the following consequences be? (damage to property, } \\
\text { infrastructure, agriculture; loss of life if there were no evacuation) }\end{array}$ & $\begin{array}{l}\text { 7-point scale; } 1=\text { not at all serious; } \\
7=\text { extremely serious }\end{array}$ \\
\hline Plans & $\begin{array}{l}\text { How effective do you think plans to [warn the population close } \\
\text { to the volcano/warn the population more widely/evacuate people } \\
\text { near the volcano] are? }\end{array}$ & $\begin{array}{l}\text { 7-point scale; } 1=\text { not at all effective; } \\
7=\text { very effective }\end{array}$ \\
\hline Personal effectiveness & $\begin{array}{l}\text { How effective do you think you would be if you had to improvise } \\
\text { a response to an eruption if you were unprepared? }\end{array}$ & $\begin{array}{l}\text { 7-point scale; } 1=\text { not at all effective; } \\
7=\text { very effective }\end{array}$ \\
\hline Statements on religion & $\begin{array}{l}\text { To what extent do you agree with the following statements? } \\
\text { (We must make offerings to the volcano so that it does not erupt; } \\
\text { If we show respect to the volcano, it will not erupt; we must } \\
\text { pray that the volcano does not erupt) }\end{array}$ & $\begin{array}{l}\text { 7-point scale; } 1 \text { = strongly disagree; } \\
7=\text { strongly agree }\end{array}$ \\
\hline
\end{tabular}

\section{Sampling methods}

The survey was initially advertised on the UNAM website and then also on the CENAPRED website: it was a convenience sample. This means that it targeted respondents who have a particular interest in volcanic risk, and therefore, the sample is not likely to be fully representative of the population in general. However, it does represent some people interested and engaged with the issues. Such people may well include many opinion formers in the community and those who become particularly engaged during an emergency. The sample is also limited to those with Internet access and so may miss a substantial portion of the population, especially in rural areas. The National Institute of Statistics and Geography state that $68.5 \%$ of Mexican citizens who use the Internet are under 35, and $47 \%$ of households across Mexico have an Internet connection. Those who do tend to be more educated and to use the Internet as a means of communication (IGEPN 2017). We discuss these possible biases further in the "Results" section but note here that while it may affect the mean values for variables and how they are interpreted, it does not affect structural results (of correlations, etc.) and therefore does not impact the objectives of the study in analysing trust and warnings. During periods of high volcanic activity, the response 
rate to the survey increased significantly (Table 2). Since the survey was of long duration, it is possible that other temporal factors affected perceptions as well as those covered in the results. However, the survey was very clearly referring to volcanic risk from Popocatépetl and we would assert that such influences are likely to be minor. We did check the IP addresses of respondents to ensure that no one took the survey multiple times.

\section{Statistical methods}

Initially, the demographic data were assessed for normality and multicollinearity. There were significant correlations between some of the variables, including, for obvious reasons, age and time living near the volcano. Care was taken in further analysis to take such intrinsic correlations into account. Since many of the variables violated normality assumptions, nonparametric tests were used to assess the dataset in more detail (Field 2000).

Differences between groups (for variables such as level of education, gender and alert level) were assessed using the Mann-Whitney $U$ test and the Kruskal Wallis nonparametric ANOVA $(H)$. These methods rank the medians of each variable in each class and look for significant differences. The $U$ test is a non-parametric equivalent of an unpaired $t$ test (Field 2000). Results for any significant $U$ tests are provided with standardised statistics ( $z$ values) to aid interpretation. The $z$ score standardises the result to a normal distribution with a standard deviation of 1 and a mean of zero.

Correlations between scale variables were assessed using Spearman's correlation coefficient ( $\rho$, below), since this is appropriate for non-parametric data. Where multicollinearity was suspected, partial correlations were carried out using Pearson's test (reported as $R$, below). The chi-square test was used to examine relationships between categorical variables. Finally, hierarchical regression was carried out.

Correlations that were statistically significant are reported. Others are reported if relevant. While the value of the correlation coefficient measures the magnitude of the relationship, the $p$ value indicates whether or not, in a dataset of this size, the relationship is significant. The $p$ value is the probability that the correlation would occur if there was no relationship between the variables. This is important because it takes into account the size of the dataset as well as the relationship between the variables in large datasets, and there is potential for wide variation. Correlations with a $p$ value $<0.05$ are typically considered significant, and those with $p<0.01$ or 0.001 are highly significant.

A list of question types and the scales used to assess them are shown in Table 1. In addition to the measured variables, several additional variables were computed, following reliability analysis. These are shown in Table 3, with appropriate reliability scores. Cronbach's alpha score was used to assess the reliability: whether or not all the items in the new variables are measuring the same thing. It does this by calculating the covariance matrix between the variables and looking at the variance within each variable to assess whether or not the variables are measuring similar things:

$\alpha=\frac{N^{2} \overline{c o v}}{\sum s_{\text {item }}^{2}+\sum \operatorname{cov} v_{\text {item }}}$

In this equation, $s^{2}$ is the variance, cov is the covariance and $N$ is the number of items on the scale. There is debate about the value of alpha that indicates a reliable scale, particularly as the value is influenced by the number of items on the scale and the context of measurement is also important (Field 2000). For studies such as this, a value of 0.7 is thought to indicate a good level of reliability (Cortina 1993), though some authors suggest that lower values would be adequate.

These combined variables are calculated to allow us to investigate whether there are predictors that might explain why some people are generally more trusting than others, for example. The strong correlation between responses to all the groups within a category (represented by high $\alpha$ in Table 3) suggests a degree of anchoring: those who generally trust one group also give high values for the other groups relative to other respondents. Averaging the variables means that we can explore some of these factors as well as the predictors for trust in individual groups.

Finally, a number of other codes were used. Nationality was coded numerically. Gender was coded as zero or one.

Table 2 Volcanic activity, alert levels and number of respondents in each timeframe

\begin{tabular}{|c|c|c|c|}
\hline Date of volcanic activity & Activity & Alert level & Respondents \\
\hline 18 Sept 2012-12 May 2013 & Gas and ash plumes, incandescence & Yellow 2 & 78 \\
\hline 12 May-7 June 2013 & Enhanced seismicity, explosions & Yellow 3 & 169 \\
\hline 7 June-5 July 2013 & Gas and ash plumes, small explosions & Yellow 2 & 34 \\
\hline 6 July-23 July 2013 & Enhanced seismicity, explosions, lava dome building & Yellow 3 & 63 \\
\hline 23 July 2013-27 March 2014 & Gas and ash plumes & Yellow 2 & 58 \\
\hline
\end{tabular}


Table 3 Variables calculated for analysis, with Cronbach's alpha for reliability

\begin{tabular}{lll}
\hline Variable name & Description & Cronbach's alpha \\
\hline All_trust & Average of trust variables & 0.77 \\
All_know & Average of 'know' variables & 0.81 \\
All_accurate & Average of under-/overestimate variables & 0.79 \\
All_soc_interest & Average of serving society's interest variables & 0.82 \\
False alarm & Average of two statements about false alarms & 0.58 \\
Precaution & Average of two statements about precaution & 0.86 \\
Av_impact & Average of damages and loss of life variables & 0.77 \\
Av_plans & Average of effectiveness of plans variables & 0.92 \\
Av_rel & Average of religion variables & 0.76 \\
All_haz & Average of hazard likelihoods & 0.89 \\
\hline
\end{tabular}

Job and level of education were coded numerically. The time at which the survey was completed allowed for a code for volcanic alert level to be computed for each respondent. During the period of the eruption, the alert level oscillated between 'yellow phase 2' and 'yellow phase 3'.

\section{Results}

\section{Sample}

The survey was completed by 402 respondents over the research period. The average age of respondents was $36(\mathrm{sd}=$ 15), $57 \%$ were male and $95 \%$ were Mexican citizens. In terms of occupation, $49 \%$ were employed full-time, $30 \%$ were students, $7 \%$ worked part time, $6 \%$ were housekeepers, $5 \%$ were unemployed and $3 \%$ retired. In total, $56 \%$ considered that they lived close to the volcano, and of these, $90 \%$ lived within $100 \mathrm{~km}$ and 55\% had lived close to the volcano for more than 20 years. Only $3 \%$ lived within $10 \mathrm{~km}$ of the volcano, and $26 \%$ lived within $25 \mathrm{~km}$. Demographic data from the National Institute of Statistics and Geography suggests that the median age of Mexicans in this region is 33 (but we excluded children from the survey-accounting for this gives a median in the age bracket 35-39). The data is slightly biased relative to the gender of respondents, since there are slightly more women than men in this region. The employment data are representative, but data are not available for other categories (such as students or housekeepers).

The spatial representation of the survey respondents, based on distance and the fact that many of them wrote down their hometowns, allowed us to test for differences between 37 residents of the Distrito Federal and 25 residents of Puebla town, and there were no significant differences. During the time of this study, the dominant plume directions in summer and autumn were broadly to the west, northwest and southwest, and in spring and winter to the east, northeast and southeast (with short-lived exceptions), so most of the populated areas close to the volcano (in all directions) experienced periodic ashfall. Ashfall events were relatively rarely recorded in major metropolitan areas. There were some larger explosions in early July 2013 that sent ash as far as Mexico City (NW), and an event on 7 March 2013 sent ash to Puebla to the east (though no one answered the survey on this date). On 13 April, ashfall was recorded around Puebla. Airport disruption also occurred in both Mexico City and Puebla in July 2013. The weather patterns and the patterns of ashfall reports suggest that the plume drifts over most of the region over the course of a year. Furthermore, the vast majority of respondents lived further than $20 \mathrm{~km}$ from the volcano and less than $100 \mathrm{~km}$ and would not suffer significant impacts from activity of the magnitude experienced during most of the period 20122014. This is also consistent with new hazard maps published by the CENAPRED in 2016, which suggest that there is no single prevailing wind direction, that most areas between 20 and $100 \mathrm{~km}$ from the volcano (90\% of respondents) are subject to ashfall and that therefore almost all respondents to this study would see minor ashfall at times. ${ }^{1}$ More than $50 \%$ of respondents are within $40 \mathrm{~km}$ of the crater, and at this distance, there is no directionality at all. It is likely, therefore, that almost all respondents have experienced some level of ashfall, and that distance, rather than direction, is a greater influence.

The survey sample was obtained over a period of 565 days, and the temporal evolution of the sample was assessed. The majority of responses (70\%) were received between 200 and 300 days after the onset of the survey. For $42 \%$ of responses, the volcanic alert level had been set at 'yellow phase 2', and for the remaining $58 \%$, it was set at 'yellow phase 3'. The rate of response during phase 3 alerts was higher than that at phase 2 , perhaps because of a larger number of people accessing the CENAPRED website for information about the volcano. The demographic of people accessing the survey at the two alert levels did not show significant differences for age, distance from volcano, time spent near the volcano, level of education

\footnotetext{
$\overline{{ }^{1} \mathrm{http}: / / \mathrm{www} . a t l a s n a c i o n a l d e r i e s g o s . g o b . m x / a p p / V i s o r P o p o c a t e p e t l ~(a c c e s s e d ~}$ 18 February 2018)
} 
or gender. However, during alert level 3, more people who were identified as housekeepers took the survey.

\section{Hazard, frequency and concern about eruptions}

Most of the respondents regarded all of the hazards as relatively likely (Table 4), though there was some variationlower values show the most likely hazards as perceived by respondents. Further uncertainty is detectable in the estimates of the size of areas likely to be affected by each hazard (Table 5): the lower values of $N$ may suggest that many people were not comfortable with making this assessment at all, and the standard deviations are all higher than the mean values, showing that there was a very wide range of assessments.

Concern about the volcano was generally skewed towards 'extremely concerned' $(M=4.5, \mathrm{sd}=1.8, N=392)$. This is unsurprising, since the survey was advertised on a website most likely to be frequented by those concerned about the volcano. This variable correlated with all of the hazard likelihoods except ash and gas and also correlated with expected length of pyroclastic flows $(\rho=0.14, p<0.01)$. It also correlated with expectations about the need for temporary $(\rho=0.26, p<0.001)$ or permanent $(\rho=0.27, p<0.001)$ evacuations and with expectations about damage $(\rho=0.27, p<0.001)$ and loss of life $(\rho=$ $0.23, p<0.001)$. People who were very concerned were also more likely to favour precaution $(\rho=0.23, p<0.001)$ and be less worried about false alarms $(\rho=-0.12, p<0.05)$.

Concern about the volcano also showed significant test results based on the alert level at the time that the respondent filled in the survey (Fig. 3). Respondents who filled in the survey when the alert level was 'yellow phase 2' tended to be less concerned than those who filled it in when the alert level was 'yellow phase 3' $(U=22,927, z=3.95, p<0.001)$. Ashfall was recorded in urban areas during both alert levels, and so it seems likely that this effect is linked specifically to the alert level and not to the volcanic activity itself.

From the demographic variables, people who lived closer to the volcano were more likely to regard gas emissions as

Table 4 Means and standard deviations for the likelihood of each hazard ( 1 = extremely likely; 7 = extremely unlikely)

\begin{tabular}{llll}
\hline Variable & Mean & $\begin{array}{l}\text { Standard } \\
\text { deviation }\end{array}$ & $N$ \\
\hline Lava flows & 3.30 & 1.96 & 387 \\
Ashfall & 2.39 & 2.24 & 381 \\
Pyroclastic flows & 3.12 & 1.88 & 385 \\
Explosive & 3.21 & 1.89 & 383 \\
$\quad$ eruptions & 3.47 & 1.90 & 378 \\
Debris flows & 3.14 & 1.87 & 373 \\
Mudflows & 2.70 & 2.13 & 381 \\
Gas emissions & & & \\
\hline
\end{tabular}

Table 5 Means and standard deviations for estimates of hazard dimensions and estimates of frequency of eruptions

\begin{tabular}{lllll}
\hline Variable & Mean & Min & Max & $N$ \\
\hline Lava flow length & $21 \mathrm{~km}$ & $0 \mathrm{~km}$ & $250 \mathrm{~km}$ & 308 \\
Pyroclastic flow length & $28 \mathrm{~km}$ & 0 & $378 \mathrm{~km}$ & 319 \\
Ash dispersion & $631 \mathrm{~km}$ & 3 & $20,000 \mathrm{~km}$ & 331 \\
Number of eruptions & 63 & 0 & 1050 & 281 \\
$\quad$ per year & & & & \\
\hline
\end{tabular}

Note that the standard deviation for ash dispersion is influenced by the extensive range of this variable ( 3 to $20,000 \mathrm{~km}$ )

unlikely ( $\rho=-0.17, p<0.01$ ) but think that ash could travel further $(\rho=0.24, p<0.001)$. They were also more likely to regard evacuation plans and warning plans as less effective ( $\rho=0.87$ and $0.24, p<0.001)$ and think that temporary evacuations would not be necessary $(\rho=0.20, p<0.01)$. They were also more likely to be concerned about false alarms $(\rho=-0.18, p<0.01)$. Older people tended to regard eruptions as more frequent $(\rho=0.18, p<0.01)$ and regard ash and lava as travelling further from the volcano $(\rho=0.20$ and 0.13 , $p<0.01,0.05)$.

\section{Forecasting variables}

Older people tended to think that forecasting eruptions on a yearly basis was more difficult $(\rho=0.128, p<0.05)$ - possibly because they had lived close to the volcano for longer (this variable correlated with the age variable, $\rho=0.165, p<0.05$ ). This might imply that longer experience on the volcano had given them greater awareness of the challenges. There were negative correlations between age/time close to the volcano and some of the knowledge, accuracy and trust variables-

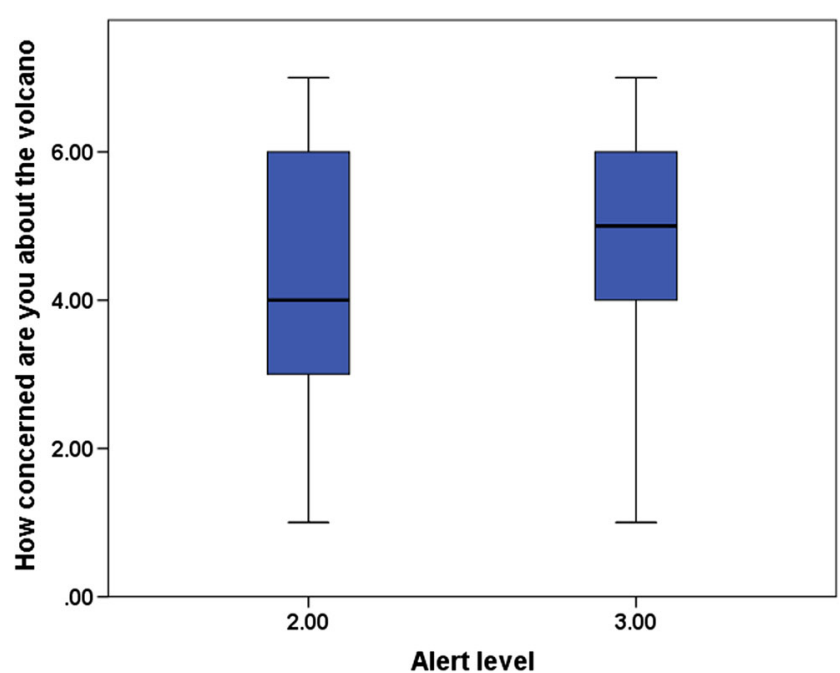

Fig. 3 Boxplot showing the distributions of the concern level variable at different alert levels 
although not with perceptions of the scientists in each of these categories. Those who thought it was very difficult to forecast eruptions tended to think that governments, friends and family and religious leaders know very little about the volcano, and also that forecasts made by governments, social networks and media would be inaccurate. They tended not to trust the governments or the media. These correlations are shown in Table 6. It is notable that Cronbach's $\alpha$ for these two variables was low: people clearly distinguished between the two timescales - the variables were measuring different things, suggesting that people viewed long-term forecasting challenges as different to those from week to week. People who thought that forecasting was difficult also tended to think that plans for evacuation and warnings were ineffective (Table 6).

\section{Impacts, evacuations and plans}

Those who had lived close to the volcano for a long time tended to think property damage would be less serious ( $\rho=$ $0.19, p<0.01)$ and regard eruptions as frequent $(\rho=0.18$, $p<0.05)$. People living further away from the volcano were more likely to think evacuation and warning plans are effective $[\rho=0.28$ (effectiveness of local warnings), $\rho=0.25$ (effectiveness of wider warnings), $\rho=0.23$ (effectiveness of evacuation plans); $p<0.001$ for all variables]. These variables and the impact variables also showed clear correlations with perceptions about knowledge and accuracy of different groups, particularly official sources-scientists and governments.

\section{Religion}

Older people tended to be sceptical about making offerings to the volcano as a means of lessening its impacts $(\rho=0.12$, $p<0.05$ ) - they were less in favour of religious approaches to the volcano. During alert level 3 , trust in religious leaders tended to be slightly higher $(\rho=0.12, p=0.024$, controlling for job because this demographic shifted with alert level, with more housekeepers taking the survey at level 3) - this was also the case for perceived knowledge and societal interests of religious leaders. These effects are relatively small but significant at the 5\% level. There were a number of interesting correlations between the religion variables and trust. Those who were generally trusting also tended to give positive responses about making offerings to the volcano ( $\rho=0.14$, $p<0.01)$ and prayer $(\rho=0.15, p<0.01)$. Retired people and housekeepers tended to agree that 'we should pray that the volcano does not erupt' $(H=21, p<0.001)$.

\section{Precaution and false alarms}

In general, far more people advocated precaution $(M=6.41$, $\mathrm{sd}=1.34)$ than were anxious about false alarms $(M=3.70$, $\mathrm{sd}=1.90)$. Older people were more likely to be concerned about false alarms $(\rho=0.11, p<0.05)$. People who were very concerned about the volcano in general tended to be less worried about false alarms and more positive about precaution $(\rho=-0.12, p<0.05$, and $\rho=0.23, p<0.001)$. Concern with false alarms was also linked to a perception that scientists are
Table 6 Significant correlations between causal factors, trust and planning variables (Spearman's)

\begin{tabular}{lcc}
\hline & Forecasting week to week & Forecasting year to year \\
\hline Knowledge of Mexican government & -0.15 & -0.14 \\
Knowledge of local government & -0.13 & -0.16 \\
Knowledge of friends/family & -0.15 & \\
Knowledge of religious leaders & -0.16 & -0.12 \\
Knowledge of social networks & & -0.16 \\
Accuracy of Mexican government & 0.19 & 0.25 \\
Accuracy of local government & 0.20 & 0.19 \\
Accuracy of social networks & 0.21 & 0.19 \\
Accuracy of news media & 0.19 & 0.17 \\
Trust in Mexican government & -0.12 & \\
Trust in local government & -0.11 & -0.19 \\
Trust in social networks & & -0.12 \\
Trust in news media & -0.17 & -0.13 \\
Effectiveness of local warnings & -0.13 & \\
Effectiveness of wider warnings & -0.18 & \\
Effectiveness of evacuation plans & -0.21 & \\
Effectiveness in improvising & & \\
\hline
\end{tabular}

Values in italics indicate significance $<0.01$. All other values significant at $5 \%$ level 
not accurate $(\rho=0.17, p=0.001)$. Those with lower levels of education tended to agree that unnecessary warnings do more harm than good $(H=14.448$, $p<0.05)$. People who advocated precaution were more likely to think that damages would be greater from an eruption and that scientists are trustworthy and that scientists, friends and family and the governments all serve society's interests (Table 7). Women were more likely to think that scientists and both national and local governments would either over- or underestimate the risk.

Table 7 shows that there are strong associations between the statements and perceptions of the motives of various groups. In particular, people who felt that warnings should be issued also had charitable views about the altruism of authorities. This view was also associated with confidence in scientists' knowledge and accuracy (note that a low value for accuracy suggests that the group is unlikely to over/underestimate the risk, and so is accurate). Distrust in scientists' accuracy was also a factor in concern about warnings (statement 4). In other words, people who thought that scientific uncertainty is high were also worried about false alarms.

\section{Trust}

Confidence in religious leaders was higher during alert level 3 than alert level $2(U=18,726, z=2.59, p<0.01)$, however while trust in scientists was slightly lower in alert level 3 $(U=14,766, z=-2.131, p<0.05)$. The extent to which the news media were viewed as serving society's interest also varied between alert levels $(U=18,843, z=2.313, p<0.05)$ : they were viewed as more altruistic at alert level 3 . Women were less likely to trust the Mexican government $(U=14,113$, $z=-2.17, p=0.03)$. Trust in scientists, the governments and news media correlated with the perceived knowledge of scientists, while trust in each group correlated with that group's knowledge. This was also the case for perceived societal interest. For accuracy, this was the case for all groups except the news media.

The Kruskal-Wallis results show that people with primary level or no education were a little more sceptical about how much scientists know $(H=14.328, p<0.05)$. Those with higher degrees tended to think that the news media were less knowledgeable $(H=14.827, p<0.05)$.

\section{Regression models}

We carried out multiple regression on the dataset to investigate predictors of trust and then split the dataset by alert level (Table 8). In all the models for 'all trust', the most powerful predictor was 'all know': the perceived knowledge of each group was strongly associated with trust. Perceived bias towards the interests of the society explained $<10 \%$ of the

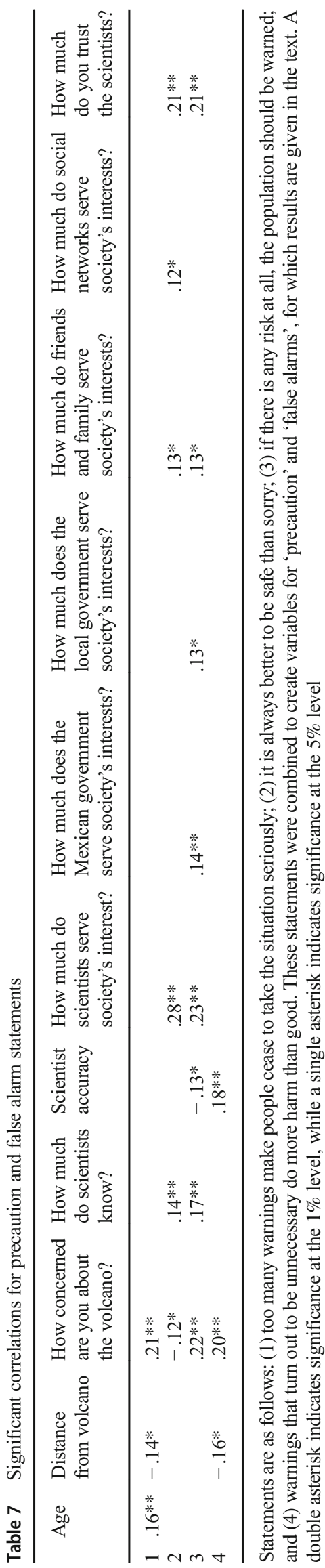


Table 8 Regression results for trust in all groups, using all data together, then using data at each alert level separately

\begin{tabular}{llrrr}
\hline Alert level & Modelled variables & \multicolumn{2}{l}{$t$} & \multicolumn{1}{l}{$p$} \\
\hline All & Knowledge & 0.37 & 7.51 & $<0.001$ \\
$R^{2}=0.51$ & Society's interest & 0.33 & 6.90 & $<0.001$ \\
& Plans & 0.18 & 4.19 & $<0.001$ \\
& Accuracy & -0.11 & -2.63 & $<0.001$ \\
2 & Knowledge & 0.43 & 5.13 & $<0.001$ \\
$R^{2}=0.43$ & Society's interest & 0.28 & 3.32 & 0.001 \\
& Religious fervour & 0.17 & 2.33 & 0.022 \\
3 & Knowledge & 0.38 & 6.16 & $<0.001$ \\
$R^{2}=0.59$ & Society's interest & 0.31 & 5.04 & $<0.001$ \\
& Plans & 0.21 & 3.97 & $<0.001$ \\
& Accuracy & -0.15 & -2.92 & 0.004 \\
\hline
\end{tabular}

variance, as did plans and perceived accuracy. There was a slight difference between those who took part during alert level yellow 2 and those at alert level yellow 3: when the alert level was lower, the accuracy variable was excluded from the model and other variables added to the dataset. At alert level yellow 2, the religious variables explained a small amount of variance (2.8\%). At level 3, planning became more important, with accuracy also included (Table 8).

The data suggest that in general, trust is dependent on how much a group is perceived to know. However, the accuracy of a risk assessment is less important than whether or not it is regarded as serving society's interests. This is consistent with previous studies (Eiser et al. 2015; Eiser et al. 2009), which have shown that the perceived altruism of the source of an assessment is more important than the accuracy. The effectiveness of plans was also considered important.

Taking into account variations between the groups, we also carried out modelling for trust in each group with predictors suggested by correlations and previous work. These results are shown in Table 9. In general, the predictors explain 40-50\% of the variance. Knowledge was entered first, followed by societal interest and then the other predictors. Predictors explaining very small amounts of variance $(<1 \%)$ were removed from the model. The data show that the efficacy of warning and evacuation plans was a factor for scientists, governments and news media, while concern about the volcano was associated with friends and family and news media. Oddly, positive responses to the religion variables were associated with trust in social networks but not religious leaders, while both of these models also incorporated accuracy. Note that for scientists, societal interest was actually more important than perceived knowledge.

Regression analysis was also carried out for precaution, but there were no significant predictors. For the false alarm statements, separate regressions and a combined regression were carried out (because of the low Cronbach's alpha). Age was the only significant predictor for 'too many warnings make people cease to take the situation seriously', and this only explained $2 \%$ of the variance. For 'warnings that turn out to be unnecessary do more harm than good', the perceived accuracy of scientists was significant for $2 \%$ of the variance. For perceived impacts, the only significant predictor was level of concern about the volcano, and this explained $11 \%$ of the variance $(\beta=0.34, t=4.64, p<0.001)$. Splitting the dataset by alert level, there was a small effect for precaution: at alert level 2, scientists' perceived knowledge explained $5 \%$ of the variance, and at level 3, concern about the volcano explained $3 \%$ of the variance. Interestingly, for the 'warnings that turn out to be unnecessary...' statement, there were no predictors at level 2, but at level 3, scientists' accuracy explained 5\% of the variance, suggesting that all of the effect in the dataset was at the higher alert level.

All regression analyses were assessed for multicollinearity using Durbin-Watson's statistic, the variance independence factor and eigenvalue diagnostics. There were no significant effects.

Figure 4 shows a visual summary of the results.

\section{Discussion}

\section{Concern about the risk}

The results demonstrate that, in general, respondents who thought that the hazards from the volcano were more likely and greater in magnitude than others also tended to express concern about the volcano and perceive its impacts as greater than other respondents: the perceived hazard appears to relate directly to the perceived risk. The fact that this concern was greater during 'yellow phase 3' suggests that the alert level system may aid risk awareness among the population and contributes to the communication of risk. While this is not surprising and is part of the purpose of alert levels (Fearnley and Beaven 2018; Mileti and Sorensen 1990; Sorensen 2000), the fact that it was independently measured in different participants over two different alerts is a strong indicator of effectiveness of the system in this context. Contributing factors to increased awareness include greater news media interest, additional advisories being sent out when the alert level is raised and more direct evidence of increased activity or unrest such as felt earthquakes, increased gas emissions and small explosions.

\section{Proximity}

There is also some evidence that residents who live closer to the volcano think that the potential consequences of an eruption are less significant, and trust evacuation plans less. Older people were more likely to think that the eruptions are 
Table 9 Regression results for each group individually

\begin{tabular}{|c|c|c|c|c|}
\hline Group & Variable & $\beta$ & $t$ & $p$ \\
\hline \multirow[t]{4}{*}{ Scientists $\left(R^{2}=0.45\right)$} & Knowledge & 0.29 & 6.48 & $<0.001$ \\
\hline & Society's interest & 0.38 & 8.61 & $<0.001$ \\
\hline & Plans & 0.17 & 4.23 & $<0.001$ \\
\hline & Accuracy & -0.16 & -3.97 & $<0.001$ \\
\hline \multirow[t]{3}{*}{ Mexican government $\left(R^{2}=0.44\right)$} & Knowledge & 0.32 & 6.71 & $<0.001$ \\
\hline & Society's interest & 0.32 & 6.58 & $<0.001$ \\
\hline & Plans & 0.21 & 5.00 & $<0.001$ \\
\hline \multirow[t]{3}{*}{ Local government $\left(R^{2}=0.50\right)$} & Knowledge & 0.36 & 7.53 & $<0.001$ \\
\hline & Society's interest & 0.35 & 7.38 & $<0.001$ \\
\hline & Plans & 0.14 & 3.30 & 0.001 \\
\hline \multirow[t]{3}{*}{ Friends and family $\left(R^{2}=0.40\right)$} & Knowledge & 0.39 & 8.78 & $<0.001$ \\
\hline & Society's interest & 0.34 & 7.45 & $<0.001$ \\
\hline & Concern & 0.15 & 3.59 & $<0.001$ \\
\hline \multirow[t]{3}{*}{ Religious leaders $\left(R^{2}=0.42\right)$} & Knowledge & 0.41 & 9.04 & $<0.001$ \\
\hline & Society's interest & 0.32 & 7.20 & $<0.001$ \\
\hline & Accuracy & -0.15 & -3.71 & $<0.001$ \\
\hline \multirow[t]{4}{*}{ Social networks $\left(R^{2}=0.49\right)$} & Knowledge & 0.47 & 10.55 & $<0.001$ \\
\hline & Society's interest & 0.33 & 7.64 & $<0.001$ \\
\hline & Religion & 0.11 & 2.79 & 0.006 \\
\hline & Accuracy & -0.11 & -2.62 & 0.009 \\
\hline \multirow[t]{4}{*}{ News media $\left(R^{2}=0.49\right)$} & Knowledge & 0.41 & 9.16 & $<0.001$ \\
\hline & Society's interests & 0.33 & 7.68 & $<0.001$ \\
\hline & Plans & 0.17 & 4.17 & $<0.001$ \\
\hline & Concern & 0.11 & 2.77 & 0.006 \\
\hline
\end{tabular}

frequent and unpredictable. These results combine to suggest that people living near the volcano may have become used to low magnitude but frequent eruptions and are potentially at risk from larger eruptions as a consequence (e.g. should a scenario like the 2010 Merapi eruption occur (Surono et al. 2012)). There was a lack of trust in evacuation plans in those living close to the volcano, which may also be the result of past poor experiences or adversarial relationships with local authorities. This is supported by the observation that people who lived closer to the volcano were more cautious about false alarms and about the potential impacts. Proximity to the volcano thus had a complex relationship with risk
Fig. 4 A summary of the results. The arrow shows the increased concern with increasing alert level, while the dotted lines and sidebars show the relative importance of different factors in the trust of different groups - so, for example, scientists' trust was most clearly predicted by their perceived altruism, while that of social networks was knowledgebased.

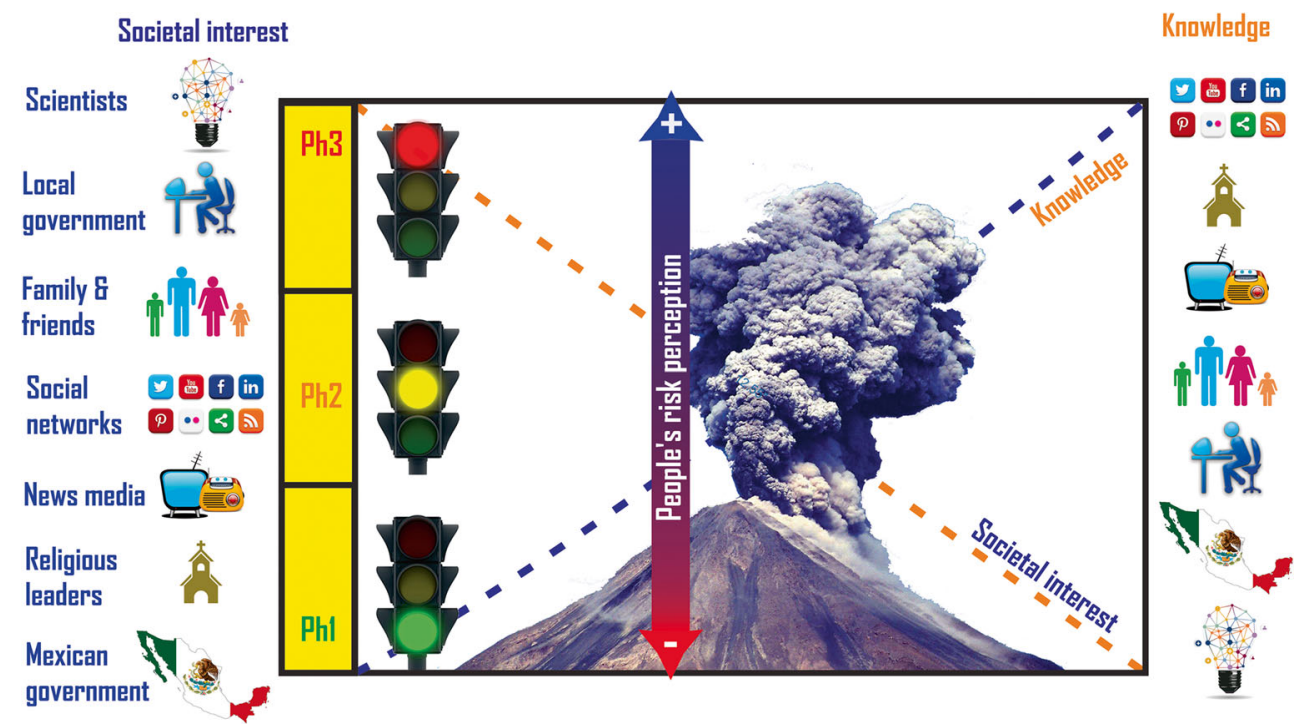


perception and perceptions of the authorities. A further study might fruitfully explore whether or not this relates to the administrative state of the respondents. Our survey did not ask for the township of respondents - we had this for 66 respondents and found no significant results, but a larger, in-country study might focus more tightly on the different states around the volcano. It may also be that plans for evacuation vary between Mexican states, and that this is an additional factor in trust. Tobin et al. (2011) noted some effects of economic conditions, which may also be a factor close to the volcano, since many of the areas closer to the volcano are less wealthy than areas closer to the metropolis of Mexico City (Coppola 2006).

\section{Trust}

The precaution, false alarms and planning variables show significant relationships with some of the knowledge, accuracy and social interest variables. In general, the data suggest that people who are happy with the planning for an eruption tend to have greater respect for the knowledge, motivations and accuracy of the groups specified in the survey.

The primary driver of trust in many of the groups was their perceived knowledge about the volcano, and the accuracy was generally less of an issue. It is interesting, however, that respondents during level 3 alerts were also slightly more likely to trust religious leaders, news media and friends and family. This can partially be explained by a slight demographic shift, housekeepers were more likely to trust these groups and they also tended to take the survey during alert level 3 (two out of 164 at level 2, 20 out of 229 at level 3). However, the increased level of concern in general at alert level 3-and the greater focus on accuracy of information-suggests that periods of raised alert do translate to greater awareness of risk and greater anxiety about the accuracy of information.

Despite the relatively small differences between alert levels, the perceived knowledge of the volcano was the most important factor in explaining trust, followed by the perceived motivation of the groups. There was some variation in the magnitude of the effect between different groups, with knowledge being particularly important in explaining trust in local government and the news media. The perceived effectiveness of plans was also a significant predictor of trust, particularly for the more 'official' sources of information about disasters, such as scientists, governments and news media-so people who feel safer in the hands of the authorities also tended to be trusting of those authorities.

It is also interesting that for scientists, perceived motivation was important and had a higher beta value than knowledge in the model. Trust in scientists was derived more from the view that they serve society's interest than from their perceived knowledge. Again, this is consistent with previous studies that have shown high effect for motivation as a predictor of trust
(Eiser et al. 2008). It is also consistent with studies of risk perception in Mexico for landslides, which also emphasise the importance of communication by groups that are perceived as altruistic (Alcántara-Ayala and Moreno 2016; Hernández-Moreno and Alcántara-Ayala 2017).

\section{Precaution and false alarms: implications for warnings}

Similar to previous studies (Eiser et al. 2015), the results suggest some links between a tendency to favour precaution in warning populations and high levels of concern about risk. This is often a matter that is of great concern to volcanologists: when should warnings be issued? This anxiety is based on the notion that alarms can be 'false'. However, as noted in the "Introduction", Eiser et al. (2012) argued for an approach based on signal detection theory and arguing that warnings under incomplete knowledge are different (visualised in Table 10). People vary considerably in their response to uncertain information, as demonstrated by the results in this paper: some people prefer to be cautious and would like all available information, while others get irritated by information that distracts them or alarms them unnecessarily. Many alert level systems function as translators for this kind of information - in Iceland, for example, a 'state of uncertainty' may be declared when volcanic unrest is high. Alert levels function as boundary objects (Star and Griesemer 1989): they seek to bring order to the science - policy encounter. Just as probabilities that are not zero or one cannot be falsified, so a tempered warning that emphasises uncertainty and lack of knowledge can aid communication in periods of unrest. This is particularly important because warnings can rarely function with the linearity that scientists would ideally like: scientists, decisionmakers and publics are social entities and cannot operate in isolation (Donovan and Oppenheimer 2014; Fearnley and Beaven 2018).

The interpretation of warnings will vary between demographic groups and will depend on individual circumstances. This paper identified groups of people who are concerned about the volcano and its impacts and who consider scientists as generally trustworthy as favouring precaution, while those concerned about scientific accuracy were concerned about false alarms. This is not surprising and underscores that clear communication of warnings is important. The fact that the concern was greater during the higher alert level, though with a small effect, suggests that alert level systems have considerable and complicated social impact and are consistent with previous work in other hazard domains (Kalkstein and Sheridan 2007). However, the emphasis in the results was on the importance of precaution-warning the public_-rather than on the dangers of false alarms. 
Table 10 Warnings and false alarms: abridged from Eiser et al. (2012)

\begin{tabular}{lll}
\hline Actual risk/decision & Eruption occurs & Eruption does not occur \\
\hline Evacuate & Success & 'False alarm' \\
Do not evacuate & Failure_lack of caution/fear of false alarms/lack of knowledge & Success \\
Learning_declare state of uncertainty/alert levels & Neither right nor wrong & Neither right nor wrong \\
\hline
\end{tabular}

\section{Limitations and future work}

The study was limited by its sample - as a convenience sample, we were not able to gain a sample representative of the population and did exclude those without Internet access, for example. In future work, we aim to look in more detail at the geography of respondents, since it is possible that risk perception is affected by (i) location in relation to hazard impacts in proximal areas, (ii) the Mexican state in which respondents are located and (iii) whether they live in urban or rural areas.

\section{Conclusions}

The results of this project demonstrate the complexities of volcanic risk perception in space and time: there were measurable differences both in the distance of residents from the volcano and in the views of respondents through time that affected their concern levels and also their levels of trust in different groups. In particular, those living closer to the volcano tended to be sceptical about risk and evacuation plans, suggesting that long experience with persistent volcanic activity may induce a level of weariness with the risk.

Trust, in general, was dominantly based on perceived knowledge across the groups but was also strongly affected by perceived motivation - those who were thought to be following society's interest tended to be more trusted. This was particularly strong for the scientist group - the main driver of trust in scientists was perceived altruism rather than knowledge. Accuracy was also a factor, but less significant.

An emphasis on scientific accuracy was, however, associated with concern about false alarms. This suggests that an element of the communication of scientific assessment around volcanoes might include emphasis on uncertainty rather than on exactitude. This concurs with other research on the communication of uncertain science (Gigerenzer et al. 2005; Harris 2015).

The results also suggest that warnings, warning systems and communication are both effective and complex in this context. Risk perception was generally increased during periods of higher activity and raised alert levels, with a more rapid uptake of the survey in these periods as well. The importance of considering the social impact of warnings is emphasised by the study, but the alert level system also functions as a boundary object - it allows the translation of risk information into terms that people can understand (Fearnley and Beaven 2018).

Acknowledgements The authors thank the three anonymous reviewers for their comments, which improved the manuscript. We also thank Costanza Bonadonna for dedicated editorial support.

Funding information This work was carried out as part of the 'VOLDIES' project (no. 228064), funded by the European Research Council. AD acknowledges a Leverhulme/Newton Trust Early Career Fellowship.

Open Access This article is distributed under the terms of the Creative Commons Attribution 4.0 International License (http:// creativecommons.org/licenses/by/4.0/), which permits unrestricted use, distribution, and reproduction in any medium, provided you give appropriate credit to the original author(s) and the source, provide a link to the Creative Commons license, and indicate if changes were made.

\section{References}

Alcántara-Ayala I (2004) Flowing mountains in Mexico: incorporating local knowledge and initiatives to confront disaster and promote prevention. Mt Res Dev 24(1):10-13

Alcántara-Ayala I, Moreno AR (2016) Landslide risk perception and communication for disaster risk management in mountain areas of developing countries: a Mexican foretaste. J Mt Sci 13(12):20792093

Boudal C, Robin C (1989) Volcán Popocatépetl: recent eruptive history, and potential hazards and risks in future eruptions, volcanic hazards. Springer, pp. $110-128$

Chester DK, Duncan AM, Dibben CJL (2008) The importance of religion in shaping volcanic risk perception in Italy, with special reference to Vesuvius and Etna. J Volcanol Geotherm Res 172(3-4):216-228

Coppola DP (2006) Introduction to international disaster management. Elsevier

Cortina JM (1993) What is coefficient alpha? An examination of theory and applications. J Appl Psychol 78(1):98-104

Crosweller H, Arora B, Brown S, Cottrell E, Deligne N, Guerrero N, Hobbs L, Kiyosugi K, Loughlin S, Lowndes J, Nayembil M, Siebert L, Sparks R, Takarada S, Venzke E (2012) Global database on large magnitude explosive volcanic eruptions (LaMEVE). J Appl Volcanol C7-4 1(1):1-13

Cvetkovich G, Lofstedt R (1999) Social trust and the management of risk. Earthscan

De la Cruz-Reyna S, Tilling RI (2008) Scientific and public responses to the ongoing volcanic crisis at Popocatépetl volcano, Mexico: importance of an effective hazards-warning system. J Volcanol Geotherm Res 170(1-2):121-134 
Dillon RL, Tinsley CH (2008) How near-misses influence decision making under risk: a missed opportunity for learning. Manag Sci 54(8): $1425-1440$

Donovan A, Oppenheimer C (2014) Science, policy and place in volcanic disasters: insights from Montserrat. Environ Sci Pol 39:150-161

Donovan AR, Oppenheimer C (2015) Modelling risk and risking models: the diffusive boundary between science and policy in volcanic risk management. Geoforum 58:153-165

Donovan A, Oppenheimer C, Bravo M (2012) Contested boundaries: delineating the "safe zone" on Montserrat. Appl Geogr 35:508-514

Donovan A, Eiser JR, Sparks RSJ (2014) Scientists' views about lay perceptions of volcanic hazard and risk. J Appl Volcanol 3(1):1

Donovan A, Eiser JR, Sparks RSJ (2015) Expert opinion and probabilistic volcanic risk assessment. J Risk Res:1-18

Doyle EE, McClure J, Johnston DM, Paton D (2014) Communicating likelihoods and probabilities in forecasts of volcanic eruptions. $\mathrm{J}$ Volcanol Geotherm Res 272:1-15

Eiser JR (1990) Social judgment. Thomson Brooks/Cole Publishing Co

Eiser JR, Fazio RH (2008) How approach and avoidance decisions influence attitude formation and change. In: Elliot A (ed) Handbook of approach and avoidance motivation. Lawrence Erlbaum, Hillsdale, pp 319-336

Eiser JR, Miles S, Frewer LJ (2002) Trust, perceived risk, and attitudes toward food technologies. J Appl Soc Psychol 32(11):2423-2433

Eiser JR, Stafford T, Henneberry J, Catney P (2007) Risk perception and trust in the context of urban brownfields. Environ Hazards 7(2):150 156

Eiser JR, Stafford T, Henneberry J, Catney P (2008) "Trust me, I'm a scientist (not a developer)": perceived expertise and motives as predictors of trust in assessment of risk from contaminated land. Risk Anal 29(2):288-297

Eiser JR, Stafford T, Henneberry J, Catney P (2009) “Trust me, I'm a scientist (not a developer)": perceived expertise and motives as predictors of trust in assessment of risk from contaminated land. Risk Anal 29(2):288-297

Eiser JR, Bostrom A, Burton I, Johnston DM, McClure J, Paton D, Van Der Pligt J, White MP (2012) Risk interpretation and action: a conceptual framework for responses to natural hazards. Int J Disaster Risk Reduction 1:5-16

Eiser JR, Donovan A, Sparks RSJ (2015) Risk perceptions and trust following the 2010 and 2011 Icelandic volcanic ash crises. Risk Anal 35(2):332-343

Fazio RH, Eiser JR, Shook NJ (2004) Attitude formation through exploration: valence asymmetries. J Pers Soc Psychol 87(3):293-311

Fazio RH, Pietri ES, Rocklage MD, Shook NJ (2015) Chapter threepositive versus negative valence: asymmetries in attitude formation and generalization as fundamental individual differences. Adv Exp Soc Psychol 51:97-146

Fearnley CJ, Beaven S (2018) Volcano alert level systems: managing the challenges of effective volcanic crisis communication. Bull Volcanol. https://doi.org/10.1007/s00445-018-1219-z

Fearnley CJ, McGuire WJ, Davies G, Twigg J (2012) Standardisation of the USGS volcano alert level system (VALS): analysis and ramifications. Bull Volcanol 74(9):2023-2036

Field A (2000) Discovering statistics using SPSS. Sage, London

Garcia C, Fearnley CJ (2012) Evaluating critical links in early warning systems for natural hazards. Environ Hazards 11(2):123-137

Gieryn TF (1983) Boundary-work and the demarcation of science from non-science: strains and interests in professional ideologies of scientists. Am Sociol Rev 48(6):781-795

Gigerenzer G, Hertwig R, Broek EVD, Fasolo B, Katsikopoulos KV (2005) 'A 30\% chance of rain tomorrow': how does the public understand probabilistic weather forecasts? Risk Anal 25(3):623629
Harris AJ (2015) Forecast communication through the newspaper part 2: perceptions of uncertainty. Bull Volcanol 77(4):30

Haynes K, Barclay J, Pidgeon N (2008) Whose reality counts? Factors affecting the perception of volcanic risk. J Volcanol Geotherm Res 172(3-4):259-272

Hernández-Moreno G, Alcántara-Ayala I (2017) Landslide risk perception in Mexico: a research gate into public awareness and knowledge. Landslides 14(1):351-371

Hincks TK, Komorowski J-C, Sparks SR, Aspinall WP (2014) Retrospective analysis of uncertain eruption precursors at $\mathrm{La}$ Soufrière volcano, Guadeloupe, 1975-77: volcanic hazard assessment using a Bayesian belief network approach. J Appl Volcanol $3(1): 3$

IGEPN (2017) Statistics related to the world Internet day

Kalkstein AJ, Sheridan SC (2007) The social impacts of the heat-health watch/warning system in Phoenix, Arizona: assessing the perceived risk and response of the public. Int J Biometeorol 52(1):43-55

Leonard GS, Johnston DM, Paton D, Christianson A, Becker J, Keys H (2008) Developing effective warning systems: ongoing research at Ruapehu volcano, New Zealand. J Volcanol Geotherm Res 172(34): $199-215$

López-Vázquez E (2009) Risk perception and coping strategies for risk from Popocatépetl volcano, Mexico. Geofis Int 48(1):133-147

López-Vázquez E, Marván ML (2012) Volcanic risk perception, locus of control, stress and coping responses of people living near the Popocatépetl volcano in Mexico. J Risk Anal Crisis Response 2(1):3-12

López-Vázquez E, Marván María L, Flores-Espino F, Peyrefitte A (2008) Volcanic risk exposure, feelings of insecurity, stress, and coping strategies in México1. J Appl Soc Psychol 38(12):2885-2902

Mileti DS, Sorensen JH (1990) Communication of emergency public warnings: a social science perspective and state-of-the-art assessment, Oak Ridge National Lab., TN (USA)

Newhall C, Punongbayan R (1996) The narrow margin of successful volcanic-risk mitigation. In: Scarpa RITR (ed) Monitoring and mitigation of volcano hazards. Springer, New York, pp 807-832

Perry RW, Lindell MK (2008) Volcanic risk perception and adjustment in a multi-hazard environment. J Volcanol Geotherm Res 172(3-4): $170-178$

Plunket P, Uruñuela G (2006) Social and cultural consequences of a late Holocene eruption of Popocatépetl in Central Mexico. Quat Int 151(1):19-28

Renn O, Levine D (1991) Credibility and trust in risk communication. Communicating risks to the public. Int Perspect 4:175-218

Shackley S, Wynne B (1996) Representing uncertainty in global climate change science and policy: boundary-ordering devices and authority. Sci Technol Hum Values 21(3):275-302

Siebe C, Macías JL (2006) Volcanic hazards in the Mexico City metropolitan area from eruptions at Popocatépetl, Nevado de Toluca, and Jocotitlán stratovolcanoes and monogenetic scoria cones in the Sierra Chichinautzin volcanic field. Geol Soc Am Spec Pap 402: 253-329

Siegrist M, Cvetkovich G (2000) Perception of hazards: the role of social trust and knowledge. Risk Anal 20(5):713-720

Sjoberg L (2008) Antagonism, trust and perceived risk. Risk Manag 10: 32-55

Slovic P (1993) Perceived risk, trust, and democracy. Risk Anal 13(6): 675-682

Sorensen JH (2000) Hazard warning systems: review of 20 years of progress. Nat Hazards Rev 1(2):119-125

Star SL, Griesemer JR (1989) Institutional ecology, translations' and boundary objects: amateurs and professionals in Berkeley's Museum of Vertebrate Zoology, 1907-39. Soc Stud Sci 19(3):387420

Surono, Jousset P, Pallister J, Boichu M, Buongiorno MF, Budisantoso A, Costa F, Andreastuti S, Prata F, Schneider D, Clarisse L, Humaida 
H, Sumarti S, Bignami C, Griswold J, Carn S, Oppenheimer C, Lavigne F (2012) The 2010 explosive eruption of Java's Merapi volcano - a '100-year' event. J Volcanol Geotherm Res 241-242: $121-135$

Swets JA (1973) The relative operating characteristic in psychology. Science 182(4116):990-1000

Tazieff H (1977) La Soufriere, volcanology and forecasting. Nature 269: 96-97

Tinsley CH, Dillon RL, Cronin MA (2012) How near-miss events amplify or attenuate risky decision making. Manag Sci 58(9):1596-1613

Tobin GA, Whiteford LM, Jones EC, Murphy AD (2007) Chronic hazard: weighing risk against the effects of emergency evacuation from popocatépetl. In: Papers and proceedings of applied geography conferences, vol 30. México, p 288

Tobin GA, Whiteford LM, Jones EC, Murphy AD, Garren SJ, Padros CV (2011) The role of individual well-being in risk perception and evacuation for chronic vs. acute natural hazards in Mexico. Appl Geogr 31(2):700-711
Van der Pligt J (1992) Nuclear energy and the public. Blackwell

White MP, Eiser JR (2006) Marginal trust in risk managers: building and losing trust following decisions under uncertainty. Risk Anal 26(5): 1187-1203

White MP, Eiser JR (2007) A social judgement approach to trust: people as intuitive detection theorists. In: Siegrist M, Earle T, Gutscher H (eds) Trust, technology, and society: studies in cooperative risk management. Earthscan, London, pp 95-116

White MP, Johnson BB (2010) The intuitive detection theorist (IDT) model of trust in hazard managers. Risk Anal 30(8): 1196-1209

White MP, Cohrs JC, Göritz AS (2011) Dynamics of trust in medical decision making: an experimental investigation into underlying processes. Med Decis Mak 31(5):710-720

Woo G (2008) Probabilistic criteria for volcano evacuation decisions. Nat Hazards 45:87-97 